\title{
The Determinants of Capital Structure in the Service Industry: Evidence from United States
}

\author{
Amarjit Gill ${ }^{*}$, , Nahum Biger ${ }^{1}$, Chenping Pai ${ }^{2}$ and Smita Bhutani ${ }^{3}$ \\ ${ }^{1}$ College of Business Administration, TUI University, CA, 90630, USA \\ ${ }^{2}$ School of Management, New York Institute of Technology, NY, USA \\ ${ }^{3}$ Geography Department, Panjab University, Chandigarh, India
}

\begin{abstract}
The paper seeks to extend Biger, Nguyen, and Hoang' (2008) findings regarding the determinants of capital structure. Empirical results show that that leverage is negatively related to the firm's profitability. This paper offers useful insights for the service industry owner/operators and managers based on empirical evidence.
\end{abstract}

\section{INTRODUCTION}

One of the tough challenges that firms face is the choice of capital structure. Capital structure decision is important because it affects the financial performance of the firm. The capital structure of a firm is defined as specific mix of debt and equity that a firm uses to finance its operations [1].

Firms can choose among many alternative capital structures. For example, firms can issue a large amount of debt or very little debt. Firms have options of arranging lease financing, use warrants, issue convertible bonds, sign forward contracts or trade bond swaps. They can also issue dozens of distinct securities in countless combinations [2].

Modigliani and Miller [3] were the first authors who developed capital structure theory. Since then, many researchers followed Modigliani and Miller's [3] path to develop new theory on capital structure and tried to departure from Modigliani and Miller's (1958) assumptions. However, the empirical evidence regarding the alternative theories is still inconclusive [4].

The determinants of capital structure have been debated for many years and still represent one of the main unsolved issues in the corporate finance literature. Many theoretical studies and much empirical research have addressed these issues, but there is not yet a fully supported and unanimously accepted theory [5]. Indeed, what makes the capital structure debate so exciting is that only a few of the developed theories have been tested by empirical studies and the theories themselves lead to different, not mutually exclusive and sometimes opposed, results and conclusions.

This study examines the determinants of capital structure in the service industry of United States. A variety of variables that are potentially responsible for determining capital structure decisions in companies can be found in the literature. In this study, the selection of exploratory variables is based on the alternative capital theories of structure and previous empirical work. The choice is sometimes limited,

*Address correspondence to this author at the College of Business Administration, TUI University, CA, 90630, USA; E-mail: AGill@tuiu.edu however, because of lack of relevant data. As a result, the final set of proxy variables includes six factors: collateralized assets, income tax, non-debt tax shield, profitability, firm size, and growth opportunities. The variables, together with theoretical predictions as to the direction of their influence on debt ratio and proxies, are summarized in Table 1.

Biger, Nguyen, and Hoang [6] and Nguyen and Neelakantan [7] have tested variables by collecting data from Vietnamese firms. This study extends the studies of Biger, Nguyen, and Hoang [6] by collecting data from the US service industry. The results can be generalized to service industry.

Most other empirical studies on the determinants of capital structure of the firm were conducted on industrial firms. There might be other factors that affect capital structure decisions in the service industries, which are not involved in manufacturing. In these industries investment in machinery and equipment is almost non-existent. If service firms lease their facilities (buildings), then their total capital invested is mainly working capital [8]. We chose not to sample companies from both service industries and manufacturing because the latter were studied before. Therefore, we focused on the service industry firms.

\section{DETERMINANTS OF CAPITAL STRUCTURE}

Because capital structure influences corporate profitability, it is important to find the important factors that influence firms' choices of leverage. Biger, Nguyen, and Hoang (2008) indicate that collateralized assets, income tax, nondebt tax shield, corporate profitability, firm size, and growth opportunities determine capital structure choices of the firm.

\section{Collateralized Assets}

Biger, Nguyen, and Hoang [6] indicate that firm's asset structure affects its leverage in both positive and negative ways. In addition, the existence of agency costs of debt may cause firms to take riskier investment after the issuance of debt to expropriate wealth from the firm's bondholders because the firm equity is effectively a stock option $[9,10]$.

Firms with high level of assets that can be used as collateral tend to use more debt rather than issue new equity be- 
cause costs associated with issuing equity rise due to the asymmetry of information possessed by insiders and outsider [6, p. 311]. The argument made by Biger, Nguyen, and Hoang [6] suggests a positive relationship between debt ratios and the firm capacity of collateralized assets. In contrast, Grossman and Hart [11] proposed that as managers have incentives to consume excessive perquisites, higher debts level would mitigate this tendency because of the higher threat of bankruptcy. This may not be the case in the service firms because these firms do not have high level of assets like manufacturing firms. Therefore, the costs associated with this agency problem would be higher for the service firms because of the lower level of collateralized assets.

\section{Profitability}

Financial leverage has a positive effect on the firm's profitability [12]. Taub [13], Nerlove [14], Baker [15], and Petersen and Rajan [16] also found a positive relationship between capital structure and profitability of the firm. In addition, Roden and Lewellen [17] found a positive relationship between profitability and total debt. Champion [18] describes that the use of leverage is one way to improve the performance of the firm. Hadlock and James [19] argue that companies prefer debt financing because they anticipate higher returns.

Fama and French [20] argue that the use of excessive debt creates agency problems among shareholders and creditors, which in turn, lead to negative relationship between leverage and profitability. Majumdar and Chhibber [21], Gleason et al. [22], and Hammes [23] found a negative effect of leverage on corporate profitability. Abor [1] examined the effect of capital structure on the corporate profitability of the listed firms in Ghana using a panel regression model. His measures of capital structure included short-term debt ratio, long-term debt ratio, and total debt ratio. Abor's [1] findings show a significantly positive relation between the short-term debt ratio and profitability. Thus, the relationship between firm's profitability and capital structures has been mixed.

Extension from perfect market setting of Modigliani and Miller [3] to the real worlds, tax-based models argue that the existence of taxes would induce profitable firms to use more debt to take advantage of tax shield from corporate tax $[6, \mathrm{p}$. 311]. In contrast, Myers and Majluf [24] refer to the pecking order and conclude that profitable firms should have tendency to use less debt. In an agency setting, financial theories predict a mixed direction. Firms with free cash flow or high profitability may tend to use earnings to pay up debt in order to avoid restraints on management discretion [6, $\mathrm{p}$. 311]. In another approach, Chang [25] considers a combination of debt and equity that can be interpreted as an optimal contract between corporate insiders and outsiders. It follows that profitable firms tend to use less debt.

In summary, empirical studies provide mixed results. Most of the empirical studies report a negative relationship between the firm's profitability and the leverage [4, 26-29]. However, Long and Maltiz [30] report leverage to be positively related to profitability but the relationship is weak.

\section{Income Tax}

Corporate income tax has important impact on debtequity choices. Modigliani-Miller proposition - the corpo- rate tax case - suggests that firms that face higher marginal tax rates should use more debt to take advantage of tax shield. Tax shield however does not apply if firms have interest free liabilities [6, p. 312]. Empirical study by MacKieMason [31] found positive relationship between debt and marginal tax rates. Huang and Song [32] using average effective tax rate to examine the Chinese listed firms found similar results.

\section{Non-Debts Tax Shield}

A large non-debt tax shield reduces the expected value of interest tax savings and lessens the advantage of debt financing. Biger, Nguyen, and Hoang [6] consider the tax deduction for depreciation and investment tax credits as non-debt tax shields (NDTS). De Angelo and Masulis [33] also suggest that tax deductions for depreciation and investment tax credits substitute the tax deduction of debt financing. In addition, empirical studies use different indicators to be proxy for non-debt tax shield, including annual depreciation expenses plus investment credit tax deflated by earnings before interests, taxes and depreciation (EBIDA) [34]; ratio of depreciation to total assets [28]; ratio of depreciation and amortization expenses scaled by total assets [32]. These studies find that leverage is negatively correlated with NDTS.

\section{Firm Size}

Many studies suggest that there is a positive relationship between firm size and leverage [7]. Marsh [35] indicates that large firms more often choose long-term debt, while small firms choose short term debt. The cost of issuing debt and equity is negatively related to firm size [7]. In addition, larger firms are often diversified and have more stable cash flows, and so the probability of bankruptcy for larger firms is less, relative to smaller firms. This suggests that size could be positively related with leverage. The positive relationship between size and leverage is also viewed as support of asymmetric information [24]. Larger size firms enjoy economies of scale and creditworthiness in issuing long term debt and have bargaining power over creditors [35]. These arguments suggest that larger firms have tendency to use higher leverage [6].

Smith [36] indicates that because small sized firms bear high costs of new equity and long term debt issuance, they may prefer to rely on short term debt and more leverage than larger sized firms. Rajan and Zingales [4] argue that larger firms tend to disclose more information to outsiders, operate under less asymmetric information and may tend to use more equity than debt. Overall, these arguments suggest a negative relationship between leverage and firm size [6].

Empirical studies generally support the positive relationship between firm size and leverage hypothesis [4, 28, 35]. In contrast, Kester [26] and Titman and Wessels [27] find a negative albeit weak and insignificant relationship.

\section{Firm's Growth}

Pecking order theory suggests that a firm's growth is negatively related to its capital structure [7]. Myers and Majluf [24] indicate that information asymmetry demands an extra premium for firms to raise external funds, irrespective of the true quality of their investment project. In the case of issuing debt, the extra premium is reflected in the higher 
required yield. High-growth firms may find it too costly to rely on debt to finance growth [7].

Growth opportunities may be considered assets that add value to a firm, but cannot be collateralized and are not subject to taxable income [27]. The agency problem suggests a negative relationship between capital structure and a firm's growth [7]. Myer [10] argued that high-growth firms might have more options for future investment than low-growth firms. Thus, highly leveraged firms are more likely to pass up profitable investment opportunities, because such an investment will effectively transfer wealth from the firm's owners to its debt holders [7]. As a result, firms with high growth opportunities may not issue debt in the first place, and leverage is expected to be negatively related to growth opportunities.

In summary, literature review shows that collateralized assets, profitability, income tax, non-debt tax shield, firm size and growth opportunities are the determinants of capital structure. Therefore, it is theorized that collateralized assets, profitability, income tax, non-debt tax shield, firm size, and growth opportunities determine the capital structure of the service firms in the service industry.

Table 1 below summarizes the determinants of capital structure, definitions and theoretical predicted signs.

\section{METHODS}

\section{Measurement}

To remain consistent with previous studies, measures pertaining to determinants of capital structure were taken from Biger, Nguyen, and Hoang's [6] studies. The study applied co-relational and non-experimental research design.

Collateralized assets (MCA) independent variable was measured as the ratio of fixed assets to total assets.

To measure profitability independent variable, we used earnings before interests, tax and extraordinary income scaled by total assets, denoted as ROA, as a proxy for firm's profitability.

To measure income tax (METR) independent variable, we used average effective income tax rate as a proxy.

To measure non-debt tax shield (MNDTS) independent variable, depreciation and amortization expenses were scaled by total assets.
Natural logarithm of sales (LnS) was used as proxy for the firm size.

Growth opportunities (GTA) independent variable was measured by the percentage of change in total assets.

Leverage (MTL) dependent variable was measured by average total liabilities divided by total assets.

Based on the literature review, determinants of capital structure can be modeled as follows:

MTL $_{i, t}=b_{0}+b_{1} *$ MCA $+b_{2} *$ ROA $+b_{3} *$ METR $+b_{4} *$ MNDTS $+b_{5} *$ LnS $+b_{6} *$ GTA $+\mu_{i, t}$

where $b_{0}=$ constant of the regression equation

$b_{1}, b_{2}, b_{3}, b_{4}, b_{5}$, and $b_{6}=$ coefficient of MCA, ROA, METR, MNDTS, LnS, and GTA

Note that all variables were calculated using book value.

MTL is defined as average total liabilities divided by total assets.

MCA- average total fixed assets divided by total assets.

ROA- Operating income divided by total assets in year 2002 .

METR- average income tax rates.

MNDTS- average non debt tax shield divided by total assets.

LnS- logarithm of sales in the year 2004.

GTA- changes in total assets through 2004-2005 deflated by total asset 2004.

$\mu_{i, t}=$ the error term.

\section{Sample and Procedures}

The study constructed a database from a selection of approximately 300 financial-reports announced by public companies between January 1, 2004 and December 31, 2005. The selection was drawn from Mergent Online [http://www.mergentonline.com/compsearch.asp] to collect a sample of service companies. Out of approximately 300 financial-reports announced by public companies between January 1, 2004 and December 31, 2005, only 158 financial reports were usable.

Most other empirical studies on capital structure were conducted on industrial firms. Therefore, we chose service industry firms (insurance services, hospitality services, telecommunication services, transportation services, business

Table 1. Proxy Variables Definition and Predicted Relationship

\begin{tabular}{|c|c|c|}
\hline Proxy Variables & Definitions \\
\hline \hline Collateralized Assets (MCA) & Fixed assets divided by total assets \\
\hline Profitability (ROA) & Earnings before interest, tax, depreciation divided by total assets, lagged one year period & Income tax divided by earnings before tax \\
\hline Effective Tax Rate (METR) & Depreciation and amortization expenses divided by total assets \\
\hline Non-Debt Tax Shield (MNDTS) & Natural Logarithm of Firm Sales, lagged one year period \\
\hline Firm Size (LnS) & Change in Total assets between two consecutive years (2004-2005) scaled by previous year \\
\hline Growth Opportunity (GTA) & & - \\
\hline
\end{tabular}


Table 2. OLS Regression Estimates on Factors Affecting Financial Leverage

\begin{tabular}{|c|c|c|c|c|c|c|c|}
\hline & \multicolumn{2}{|c|}{ Unstandardized Coefficients } & \multirow{2}{*}{$\frac{\text { Standardized Coefficients }}{\text { Beta }}$} & \multirow{2}{*}{$\mathbf{t}$} & \multirow{2}{*}{ Sig. } & \multicolumn{2}{|c|}{ Collinearity Statistics } \\
\hline & B & Std. Error & & & & Tolerance & VIF \\
\hline (Constant) & 0.701 & 0.125 & & 5.601 & 0.000 & & \\
\hline MCA & -0.141 & 0.067 & -0.171 & -2.098 & 0.038 & 0.882 & 1.133 \\
\hline ROA & -0.742 & 0.197 & -0.329 & -3.763 & 0.000 & 0.768 & 1.303 \\
\hline METR & 0.000 & 0.002 & 0.027 & 0.315 & 0.754 & 0.786 & 1.272 \\
\hline MNDTS & -0.021 & 0.073 & -0.023 & -0.288 & 0.774 & 0.891 & 1.122 \\
\hline $\operatorname{LnS}$ & -0.001 & 0.008 & -0.015 & -0.190 & 0.850 & 0.961 & 1.040 \\
\hline GTA & 0.032 & 0.051 & 0.052 & 0.638 & 0.525 & 0.886 & 1.129 \\
\hline
\end{tabular}

Dependent Variable: Leverage (MTL).

All variables are calculated using book value. MTL is defined as average total liabilities divided by total assets; MCA- average total fixed assets divided by total assets; ROA- Operating income divided by total assets in year 2004; METR- average income tax rates; MNDTS- average non debt tax shield divided by total assets; LnS- logarithm of sales in the year 2004; GTA- changes in total assets through 2004-2005 deflated by total asset 2004

services, financial services, and retail sales services) to find the determinants of capital structure.

\section{Data Collection}

Numerical (quantitative) and financial data were collected to test the hypothesis. Financial statements and proxies submitted by companies to Securities and Exchange Board of USA were used to collect data.

\section{Empirical Analysis}

In this section we present the empirical findings on the determinants of capital structure.

Test for multi-colinearity: All VIF coefficients are less than 2 and tolerance coefficients are greater than 0.5 . Nevertheless, we performed an additional regression test that is reported at the end of the section before the discussion.

Table 3. Model Summary

\begin{tabular}{|c|c|c|c|c|}
\hline Model & $\mathbf{R}$ & $\mathbf{R}^{2}$ & $\begin{array}{c}\text { Adjusted R } \\
\text { Square }\end{array}$ & $\begin{array}{c}\text { Std. Error of the } \\
\text { Estimate }\end{array}$ \\
\hline \hline 1 & $0.333^{\mathrm{a}}$ & 0.111 & 0.076 & 0.177297490 \\
\hline
\end{tabular}

Note that around $11.1 \%\left(\mathrm{R}^{2}=0.111\right)$ of the variance in the degree of leverage can be explained by the degree of GTA, MCA, LnS, MNDTS, GTA, and ROA (see Table 3).

Table 4. ANOVA ${ }^{\text {b }}$

\begin{tabular}{|c|c|c|c|c|c|c|}
\hline Model & & $\begin{array}{c}\text { Sum of } \\
\text { Squares }\end{array}$ & df & $\begin{array}{c}\text { Mean } \\
\text { Square }\end{array}$ & F & Sig. \\
\hline \hline 1 & Regression & 0.594 & 6 & 0.099 & 3.147 & $0.006^{\text {a }}$ \\
\hline & Residual & 4.747 & 151 & 0.031 & & \\
\hline & Total & 5.340 & 157 & & & \\
\hline
\end{tabular}

a Predictors: (Constant), GTA, MCA, LnS, METR, MNDTS, ROA.

${ }^{\mathrm{b}}$ Dependent Variable: Leverage (MTL)

As shown in Table 4, ANOVA's test is also significant at 0.006 . Further examination of the data indicates that some of the 'explanatory' variables exhibit relatively high correlations. Therefore, we performed an additional regression test where only explanatory variables that have non-significant linear correlations among them were included. The variable that are included are: MCA and ROA with the following results:

\begin{tabular}{|c|c|c|c|}
\hline $\mathbf{R}$ & R-Square & Adj. R-Square & S.E.E. \\
\hline \hline 0.326 & 0.106 & 0.095 & 0.1755 \\
\hline
\end{tabular}

Predictors: (Constant), ROA, MCA

In addition, the regression results were:

\begin{tabular}{|c|c|c|c|c|}
\hline & B & SE & T & P \\
\hline \hline Constant & 0.687 & 0.046 & 14.874 & 0.000 \\
\hline MCA & -0.135 & 0.063 & -2.135 & 0.034 \\
\hline ROA & -0.699 & 0.174 & -4.029 & 0.000 \\
\hline
\end{tabular}

Dependent Variable: Leverage (MTL).

Thus, two variables, MCA and ROA are statistically sufficient in providing similar explanation to the variance of the dependent variable -- the capital structure of firms in the service industry. Both variables exhibit negative relationship with the capital structure.

\section{DISCUSSION}

\section{Collateralized Assets}

Theoretical research predicts positive relationship between collateralized asset and leverage. Prior empirical studies use fixed assets as its proxy and the findings are consistent with theoretical predictions [6]. The findings of this paper show opposite result: leverage decreases as the proportion of fixed asset in the total assets of the firm increases (see Table 2). The service industry is usually characterized by a relatively low level of fixed assets. Current assets can more easily be converted to cash and thus have more liquid capacity than fixed asset. Lending institutions generally attribute more significance to the capacity to convert borrowers' assets into cash and we conjecture that in the service industry the importance of current rather than fixed assets plays an important role in their decision to offer loans to firms with 
high ratio of current to total assets, or a low ratio of fixed to total assets. This supply-side argument might explain why firms who own relatively low ratios of fixed to total assets may have higher leverage. The findings of this paper are similar to those reported by Biger, Nguyen, and Hoang [6].

\section{Profitability}

The findings of this paper are consistent with prior empirical studies that leverage is negatively correlated with profitability [4, 6, 26-29]; that is, higher profitable firms use less debt. It should be noted that the findings of this paper are inconsistent with the finding of Long and Maltiz [30] in which they indicate the positive relationship between leverage and the profitability.

We also provide some comments about the other variable that did not come out to be significant in the regression analysis.

\section{Effective Income Tax Rate}

Theoretical research predicts a positive impact of tax rate on leverage because of the tax shield effects. A nonsignificant relationship between the tax rate and leverage were found. That is, tax rate was not found to be a significant determinant of capital structure in the service industry.

\section{Non-Debt Tax Shield}

A non-significant relationship between non-debt tax shield and leverage was found. That is, tax rate is not the determinant of capital structure in the service industry.

\section{Firm Size}

Previous studies reported positive correlation between the firm size and the leverage $[4,28,29,32,35]$. We did not find significant relationship between the firm size and the leverage. That is, firm size is not the determinant of capital structure in the service industry.

\section{Growth Opportunities}

No significant relationship between the growth opportunities and the leverage was found. That is, growth opportunities are not the determinant of capital structure in the service industry.

\section{Limitations}

This study is limited to the sample of American service industry firms. The findings of this study could only be generalized to service firms similar to those that were included in this research.

\section{Future Research}

Future research should investigate generalization of the findings beyond the service sector. Important control variables such as industry sector, etc., should be used to determine other factors that influence capital structure.

\section{REFERENCES}

[1] Abor J. The effect of capital structure on profitability: empirical analysis of listed firms in Ghana. J Risk Finance 2005; 6: 438-45.
[2] Abor J. Debt policy and performance of SMEs: Evidence from Ghanaian and South African Firms. J Risk Finance 2006; 8: 36480 .

[3] Modigliani F, Miller M. The cost of capital, corporation finance and the theory of investment. Am Econ Rev 1958; 48: 261-97.

[4] Rajan RG, Zingales L. What do we know about the capital structure? Some evidence from international data. J Finance 1995; 50: 1421-60.

[5] Morri G, Beretta C. The capital structure determinants of REITs. Is it a peculiar industry? J Eur Real Estate Res 2008; 1: 6-57.

[6] Biger N, Nguyen NV, Hoang QX. The determinants of capital structure: evidence from Vietnam. Int Financ Rev 2008; 8: 307-26.

[7] Nguyen TD, Neelakantan R. Capital structure in small and medium-sized enterprises: the case of Vietnam. ASEAN Econ Bull 2006; 23: 192-211.

[8] Gill A, Biger N, Bhutani S. Corporate performance and the chief executive officer's compensation in the service industry. Open Bus J 2008; 1: 53-7.

[9] Jensen M, Meckling W. Theory of the firm: managerial behaviour, agency costs and ownership structure. J Financ Econ 1976; 3: 30560 .

[10] Myers SC. Determinants of corporate borrowing. J Financ Econ 1977; 9: 147-76.

[11] Grossman SJ, Hart O. Corporate financial structure and managerial incentives. The Eco of Information and Uncertainty: Chicago, University of Chicago Press 1982.

[12] Hutchinson RW. The capital structure and investment decisions of the small owner-managed firm: some explanatory issues. Small Bus Econ 1995; 7: 231-9.

[13] Taub AJ. Determinants of the firm's capital structure. Rev Econ State 1975 ; 57: 410-6.

[14] Nerlove M. Factors affecting differences among rates of return on investments in individual common stocks. Rev Econ State 1968; 50: 312-31.

[15] Baker SH. Risk, leverage and profitability: an industry analysis. Rev Econ State 1973; 55: 503-7.

[16] Petersen MA, Rajan RG. The benefits of lending relationships: evidence from small business data. J Finance 1994; 49: 3-37.

[17] Roden DM, Lewellen WG. Corporate capital structure decisions: evidence from leveraged buyouts. Finance Manage 1995; 24: 7687.

[18] Champion D. Finance: the joy of leverage. Harvard Bus Rev 1999; 77: 19-22.

[19] Hadlock CJ, James CM. Do banks provide financial slack? J Finance 2002; 57: 1383-420.

[20] Fama EF, French KR. Taxes, financing decisions, and firm value. J Finance 1998; 53: 819-43.

[21] Majumdar SK, Chhibber P. Capital structure and performance: evidence from a transition economy on an aspect of corporate governance. Public Choice 1999; 98: 287-305.

[22] Gleason KC, Mathur LK, Mathur I. The interrelationship between culture, capital structure, and performance: evidence from European retailers. J Bus Res 2000; 50: 185-91.

[23] Hammes K. Various aspects of capital structure in Poland. Working Paper; Tallin Technical University, Tallin 1998.

[24] Myers SC, Majluf NS. Corporate financing and investment decisions when firms have information that investors do not have. J Financ Econ 1984; 13: 187-221.

[25] Chang C. Capital structure as optimal contract. Working Paper; Carlson School of Management, University of Minnesota 1987.

[26] Kester CW. Capital and ownership structure: a comparison of United States and Japanese Corporations. Finance Manage 1986; 15: 5-16.

[27] Titman S, Wessels R. The Determinant of capital structure choice. J Finance 1988; 43: 1-19.

[28] Wald JK. How firm characteristics affect capital structure: An international comparison. J Financ Res 1999; 22: 161-87.

[29] Booth A, Demirguc-Kunt A, Maksimovic V. Capital structure in developing countries. J Finance 2001; 56: 87-130.

[30] Long M, Maltyz E. The investment financing nexus: some empirical evidence. Midl Corp Financ J 1985; 3: 53-9

[31] Mackie-Mason J. Do taxes affect corporate financing nexus: some empirical evidence. Midl Corp Financ J 1990; 3: 53-9. 
[32] Huang SG, Song FM. The determinants of capital structure: Evidence from China. School Econ Financ Center for China Fin Res, The University of Hong Kong Press for SSRN 2006.

[33] DeAngelo H, Masulis R. Optimal capital structure under corporate and personal taxation. J Financ Econ 1980; 8: 3-29.
[34] Bradley M, Jarrel G, Kim EH. On the existence of an optimal capital structure: theory and evidence. J Finance 1984; 39: 857-78.

[35] Marsh P. The choice between equity and debt: An empirical study. J Finance 1982; 37: 121-44.

[36] Smith C. Alternative methods for raising capital right versus underwritten offerings. J Financ Econ 1977; 5: 273-307.

(c) Gill et al.; Licensee Bentham Open.

This is an open access article licensed under the terms of the Creative Commons Attribution Non-Commercial License (http://creativecommons.org/licenses/by$\mathrm{nc} / 3.0 /$ ) which permits unrestricted, non-commercial use, distribution and reproduction in any medium, provided the work is properly cited. 